\title{
THE WAIOTAPU EARTHQUAKE OF 1983, DECEMBER 14.
}

\author{
Euan G. C. Smith ${ }^{*}$, Brad J. Scott ${ }^{* *}$ and John H. Latter*
}

ABSTRACT

The continual earthquake swarm activity in the Waiotapu-Waikite Valley area that commenced in April 1982, reached a climax on 14 December 1983 with the occurrence of a magnitude 5.1 shock at shallow depth, on or close to the Ngapouri fault, near Waiotapu. It was the largest event in this area for more than 40 years. Felt intensities reached MM VII and possibly MM VIII in the epicentral region and resulted in claims for $\$ 29,000$ worth of damage.

Although inadequate for the determination of a focal mechanism, first $P$-wave motions indicate that the earthquake produced east-west extension. On the assumption that the shock occurred on the Ngapouri fault (strike $N 55^{\circ} \mathrm{E}$, northwest side down), this implies sinistral movement with a lesser dip slip component. Geodetic data are consistent with extention at $N 110^{\circ} \mathrm{E}$ in the region, although the magnitude of the strain is technically too small to be statistically significant.

\section{INTRODUCTION}

The Taupo volcanic zone is a complex volcano-tectonic depression, about 40 kilometres wide, extending over 240 kilometres from White Island to Mount Ruapehu. It forms the eastern margin of the wider region of volcanism in the North Island. Over 15,000 square kilometres of lava, ignimbrite and tephra, dominantly of rhyolitic composition, has been erupted from centres in and near the Taupo volcanic zone since volcanism commenced in late and the east coast of the North Island, it is one of the more seismically active quakes reported felt there each year. However, in comparison with the east coast of the North Island, the average depth of these events is much less. ConsequentIy, smaller events are more strongly felt in the volcanic region than in the east coast region. At the same time, there have been relatively fewer large events in the volcanic region: Smith and Berryman (1984) report no magnitude seven earthquakes, and only one of magnitude $6 \frac{1}{2}$, in

A full discussion of the seismicity of this region is beyond the scope of this paper. However, to put the 14 December 1983 event into some perspective,

* Geophysics Division, Department
of Scientific and Industrial
Research, Wellington.
New Zealand Geological Survey,
Department of Scientific and
Industrial Research, Rotorua.
Pliocene time. Together with Fiordland regions of New Zealand with many earththe region since 1840 .

Figure 1 shows the epicentres of shallow earthquakes of magnitude 4.5 and greater that have occurred in and around the Taupo volcanic zone since 1940. At this magnitude level, the catalogue of earthquakes for the region shown on the map is almost complete - Robinson (1979) judges it to be complete to magnitude 4.3 since 1950 . The principal features of the seismicity shown in Figure 1 are a broad, fairly uniform band of activity at the eastern margin of the Taupo volcanic zone; a concentration of epicentres along the western and southern edges of lake Taupo that is not entirely attributable to the earthquake swarm of 1964 (Gibowicz 1973); and diffuse activity in the eastern Bay of Plenty (offshore), the diffuseness of which is likely to be caused at least in part by greater uncertainty of location. Another feature is the paucity of magnitude 5 events between Lake Taupo and the Bay of Plenty: the 1983 shock filled a gap of sorts, and was certainly the largest event for over 40 years in the region from the Rotorua lake district to Taupo.

\section{SWARMS AND THE 1983 DECEMBER SHOCK}

In the 20 month period preceding the December shock, the epicentral region was subject to repeated swarms. They began on 30 April 1982; the largest shock on that day reached magnitude 4.2 and was the second largest in the whole sequence. The chronology of the swarm is given in Figure 2, and epicentres of the events of magnitude 3 and greater are shown in Figure 3. It would seem that the sequence did not finish in December: certainly minor earthquakes occurred sporadically in early 1984. From Figures 2 and 3, it 


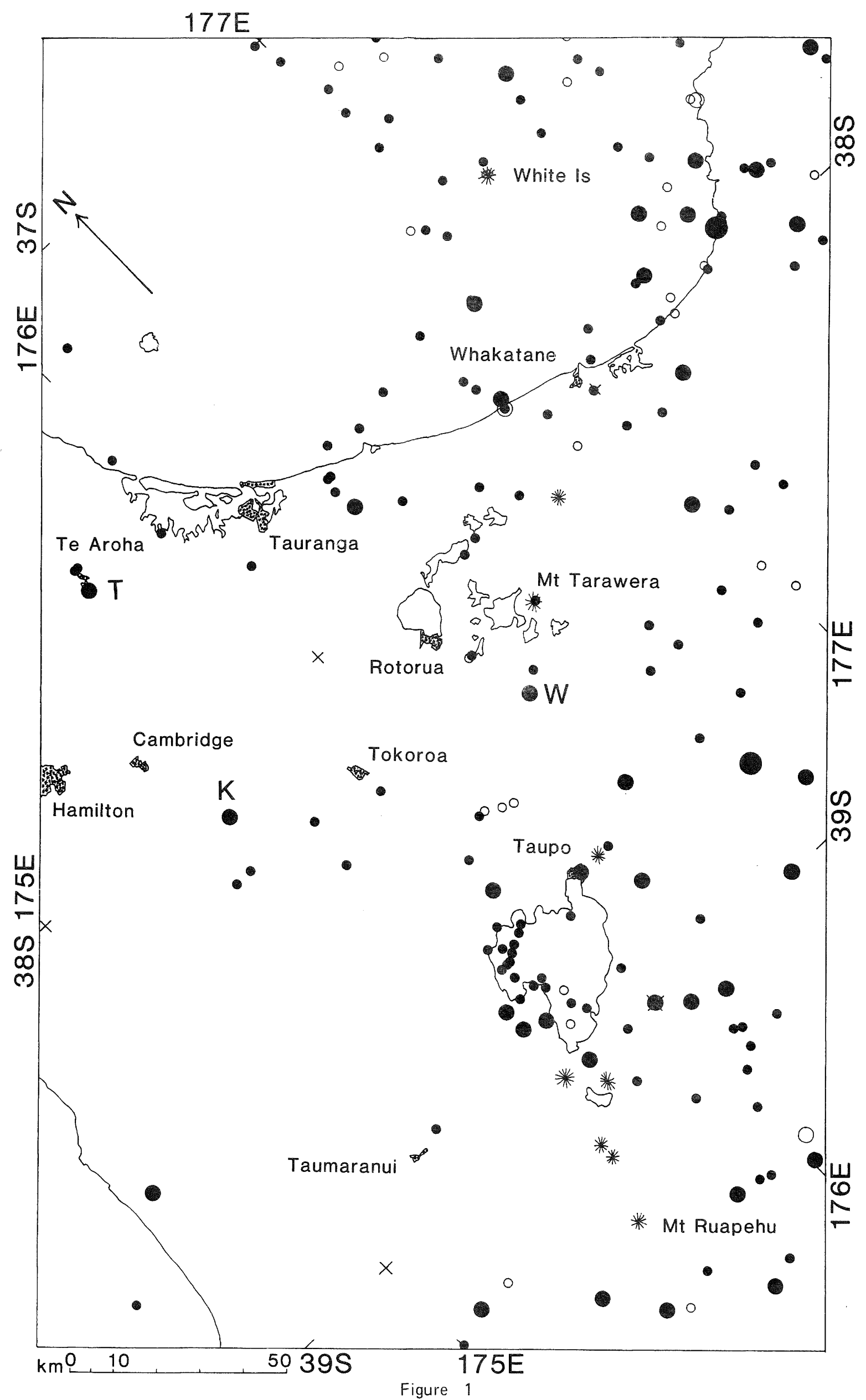

Epicentres of earthquakes of depth $\leq 40 \mathrm{~km}$ and $M \geq 4.5$ between 1940 and 1983 . Earthquakes mentioned in the text are labelled: W, Waiotapu; K, Korakonui; T, Te Aroha. Three sizes of spot denote events of $4.5 \leq M<5,5<M<6$ and $M$ 26 . Open circles denote less reliably located events. Positions of some volcanoes at the eastern margin of the volcanic region are shown as ${ }^{*} *$ 





can be seen that the epicentral region has been subject to a complex pattern of seismic activity and the implications of this pattern are not understood, although there has been no reason so far to link the swarms to future eruptive volcanism. It appears to be part of an episode of activity, also unfinished, that has affected the whole volcanic zone since April 1982 .

As far as deformation, strain release and damage are concerned, only the December shock is of much importance. The earthquake occurred at 2056.29 hours on 14 December 1983 (universal time). The epicentre, determined from data from the national seismograph network and the standard velocity model (Lowry, 1983; page 25) was $38.36 \pm 0.02^{\circ} \mathrm{S}, 176.33 \pm$ $0.02^{\circ} \mathrm{E}$. The magnitude was 5.1. Using a model developed for the volcanic zone, the epicentre was determined to be $38.362^{\circ} \mathrm{S}$ $176.316^{\circ} \mathrm{E}$. Locations of this and other earthquakes of the sequence in 1982 determined using the special model are given in Balsillie and Latter (1984). An aftershock on 18 December was recorded on a seismograph temporarily installed near Waiotapu (Figure 3 ) and a focal depth of $8+2$ kilometres was determined for this shock. This remains the best estimate of the depth of the main-shock and the activity generally. The macroseismic data, discussed below, are not inconsistent with the main-shock having occurred at this depth.

\section{FOCAL MECHANISM}

In June 1982, five seismographs were temporarily installed in the epicentral region of the 30 April 1982, M $=4.2$ shock and a few very small events were recorded during about a week of operation. Although too poorly recorded to be considered well located, the events appeared to have occurred on the Paeroa fault. They produced first P-wave motions consistent with normal faulting ( $R$ Robinson, pers comm).

First motions of $\mathrm{P}$-wave arrivals from the December 1983 shock are plotted in Figure 4. At the temporary station, both compressions and dilatations were recorded from aftershocks, indicating, on the assumption of a common focal mechanism, that a nodal plane must pass close to the position of the arrivals from the temporary station on Figure 4. The data are inadequate to construct a mechanism with any worthwhile degree of reliability, but one nodal plane, striking about $N 60^{\circ} \mathrm{E}$, is reasonably well determined. The locus of the tension axis for the range of the second nodal plane between the limits indicated on Figure 4 has been calculated and is also shown on Figure 4. It indicates that the earthquake resulted in extension at about $\mathrm{N} 100-105^{\circ} \mathrm{E}$. The proximity of the strike of the determined nodal plane to the strike of faults in the epicentral region, and the Ngapouri fault in particular, suggests that this is most likely to be the fault plane. Consequently one would deduce that the motion on the fault was primarily sinistral with an un- known, but lesser, dip-slip component, which could have been either normal or reverse. In the extreme case of the plane marked $A$ in Figure 4, the dip-slip component (reverse) would about equal the strike-slip component. A reverse dip-slip component would be consistent with the prior vertical displacement on the Ngapouri fault, which has the northwest side down.

\section{GEODETIC DATA}

Following the April 1982 earthquakes, the Department of Lands and Survey was asked to repeat a second order triangulation of the area between the Paeroa fault and Mount Tarawera made in January 1949, and this was done in June 1983.

The provisional release of this data (Flaherty et al, 1984) has allowed the horizontal strain to be estimated by the method of Bibby (1973 ard 1982). The result for the whole network is an engineering strain rate of $1.1 \pm 2 \times 10^{-7}$ radians per year with the azimuth of the principal axis of extension being $N 110^{\circ} \mathrm{E}$. Although the low rate of strain and the relatively short time interval combine to yield a result which is technically insignificant, it is in agreement with the estimate of the average secular horizontal strain rate for the Taupo volcanic zone of $1.7 \pm 0.04 \times 10^{-7}$ radians per year, with the principal axis of tension at an azimuth of $116^{\circ} \pm 26^{\circ}$, obtained by Sissons (1979), and it is supported by the azimuth of the axis of tension determined from the focal mechanism. It implies a displacement of about $50 \mathrm{~mm}$ across the network (about 15 kilometres wide) in the 34 years between surveys, which is of the right order of fault displacement for a magnitude 5 earthquake. Put another way, the December 1983 activity accounted for some 30 years of strain accumulation in the epicentral region.

\section{MACROSEISMIC DATA}

Figure 5 is an isoseismal map for the 14 December shock. The MM IV area extended from Wairakei to Rotorua and intensities reached MM VII and possibly MM VIII in the epicentral region.

Examination of the area around Waiotapu, and interviews with local residents provided reasonably detailed information about felt intensities. Two observations, indicated in Figure 5, suggested MM VIII in the epicentral region. In addition to damage to roads in areas of fill and unconsolidated material, there were large boulders up to 2 metres in diameter displaced from road cuttings on state highway 5 up to 1.5 kilometres south of Waiotapu, and there was a landslide on the steep western face of Mount Paeroa, just south of the village of Waikite Valley. Doubt about the prior stability of the displaced material leaves the assignment of MM VIII uncertain. Undoubted instances of MM VII occurred at Waiotapu and along the waikite valley Road. Mrs Hagley's house on the waikite Road near 


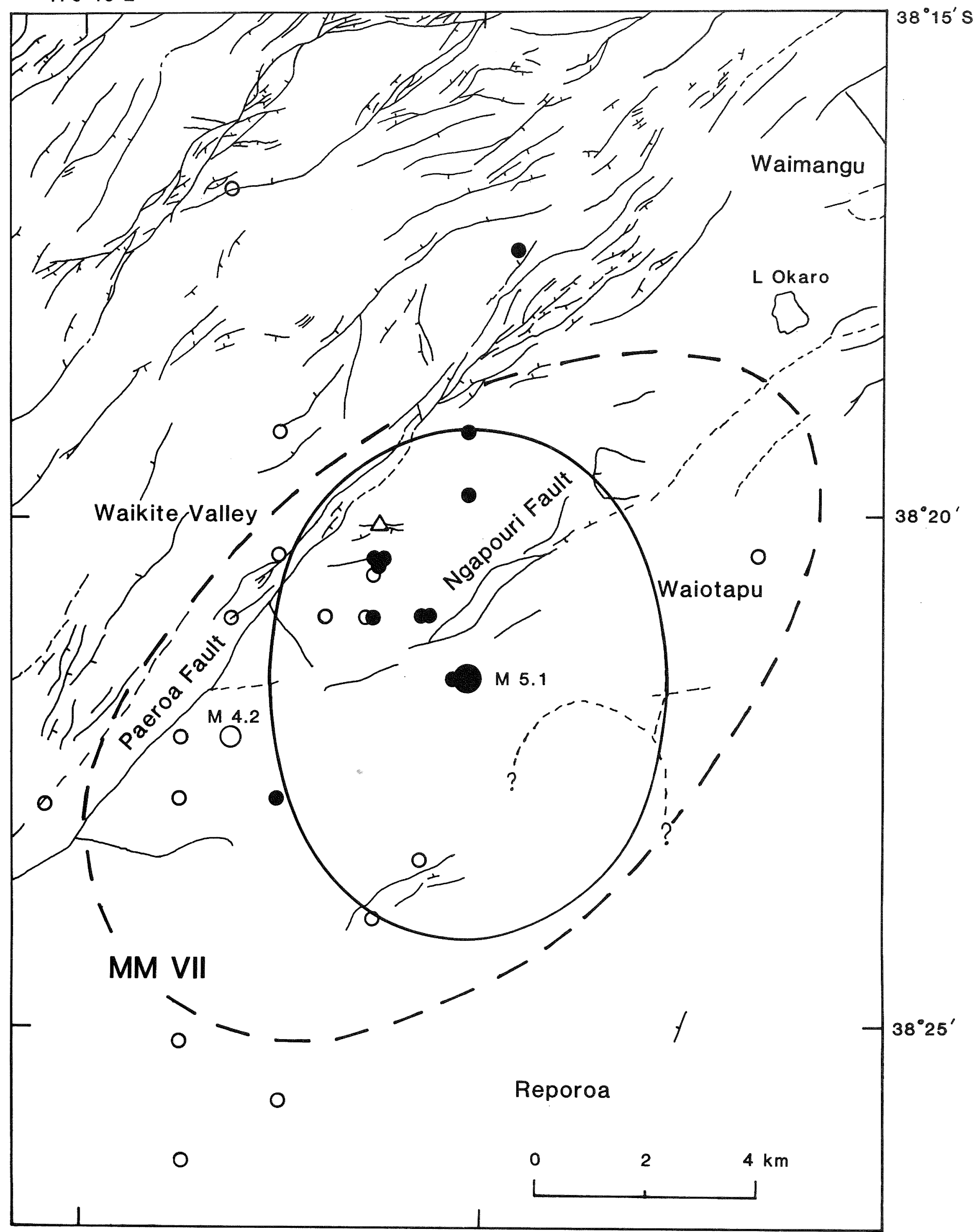


Waiotapu (near $38^{\circ} 20.5^{\prime} \mathrm{S}, 176^{\circ} 21^{\prime} \mathrm{E}$ ) had been damaged slightly by the largest of the April 1982 events. The December shock wrinkled wallpaper, sprang door and window frames up to 2-3 $\mathrm{mm}$, displaced pinex ceiling tiles and cracked gib-board stopping. No windows were broken. Cupboards were partially emptied, and all ornaments were thrown off shelves and pictures and mirrors displaced off walls. Similar damage occurred at the waiotapu thermal area tearooms. Nearby, there was minor damage to the dwelling in which a household refrigerator was overturned. There were numerous instances of $M M V I$. It was also observed that the earthquake was accompanied by short-lived changes to the thermal activity at Waiotapu. Claims for damage totalled $\$ 29,000$, including one for $\$ 3,000$ for damage to a silo at the dairy factory at Reporoa.

The MM VII isoseismal is approximately elliptical with an area of about 125 square kilometres. This is about the size of the MM VII region produced by the $M=5.1 \mathrm{Te}$ Aroha event of 1972 (Adams et al, 1972) but is only about one-eighth the area Eiby (1977) reported for the $M$ $=5.0$ Korakonui shock of 1976 (Figure 1). Eiby interpreted the unusually high intensities from that shock being due to an extremely shallow focus - perhaps as shallow as 1 kilometre. The much smaller MM VII area for the Waiotapu shock tends to confirm that its focal depth was significantly greater than this.

\section{DISCUSSION}

Two important pieces of information were provided by this shock. First, more was learned about damage from smallto-moderate shocks. No known earthquake of magnitude less than $5 \frac{1}{2}$ has produced MM VII over as wide an area as the very shallow Korakonui shock. However, the rather deeper magnitude 5 events east of the North Island ranges often produce maximum intensities of only MM $\mathrm{V}$. The Waiotapu and earlier $\mathrm{Te}$ Aroha shocks were intermediate between these extremes. This variation emphasises the need to establish the probable focal depth of moderate and larger shocks in different parts of New Zealand and incorporate this information in risk analysis. Some progress has been made in the last decade or so, via microearthquake surveys, to establish the depth distribution in different localities, and Smith (1978) made a start at incorporating regional variations in isoseismal patterns in risk assessment by way of empirical rules. With better estimates of the depths of moderately-sized events in the future, his work can be refined.

Second, the shock provided some information about the state of seismogenic stress near Waiotapu, and possibly about the stress throughout the Taupo volcanic zone. Although poorly determined, the focal mechanism had an important element in common with composite focal mechanisms recently obtained by Webb (pers comm) for two earthquake swarms on the north shore of Lake Taupo in 1983, and the mechanism obtained by Hunt and Latter (1982) for earthquakes near the Wairakei geothermal field. All four focal mechanisms indicate predominantly strike-slip deformation, and although faults with normal offsets abound in the volcanic zone, the seismic evidence, such as it is, suggests that transcurrent movement is significant in the deformation of the area.

A final remark concerns the problem of volcanic surveillance. A number of swarms in the volcanic zone in the last two years have attracted attention from scientists, local residents and the news media, partly because of the ever present risk of eruptive volcanic activity. Although the national network of seismographs provides reasonable data for post hoc analysis, the technology of the network makes impossible the sort of rapid analysis required for hazard monitoring. However, the New Zealand Geological Survey has recently purchased a recorder and telemetry link for Rotorua and is supplying the recorder for a seismograph on Mount Tarawera as part of a seismic monitoring network around Rotorua, and Geophysics Division is planning to both update the technology of the national network to provide faster analysis of events on a national scale, and to install a network around Lake Taupo. These developments are the first stages of a programme for volcanic hazard monitoring.

\section{ACKNOWLEDGEMENTS}

Thanks are due to the Earthquake and War Damage Commission for information from their files, to the Department of Lands and Survey for providing the geodetic data prior to its publication, to Mr G A Eiby for his guidance in drawing the isoseismal map, and to staff of the Seismological Observatory and New Zealand Geological Survey, Rotorua, for their comments on the paper. B J Scott thanks the Enwright family for their hospitality and assistance, especially for allowing access to operate the portable seismograph.

\section{REFERENCES}

Adams R D, Muir M G, Kean R J (1972). "Te Aroha Earthquake, 9 January 1972". Bulletin of NZ Society for Earthquake Engineering 5: 54-58.

Balsillie $F \quad H$ and Latter $J$ H (1984). "List of Earthquake Locations in and Near the Volcanic Region." In New Zealand Volcanological Record No 12, Gilchrist C A (Ed). Nz Geological Survey, Wellington.

Bibby H M (1973). "The Reduction of Geodetic Survey Data for the Detection of Earth Deformation." Geophysics Division, DSIR Report 84: 25 pages.

Bibby H M (1982). "Unbiased Estimate of Strain from Triangulation Data Using the Method of Simultaneous Reduction." Tectonophysics 82: 161-174.

Eiby G A (1977). "Anomalous Intensities Due to the Korakonui Earthquake, 5 December 1976." Bulletin of NZ Society for 
Earthquake Engineering 10: 167-169.

Flaherty M P, Bevin A $J$, Seddon D C L (1984). "Rotomahana Deformation Survey." Okataina Volcanic Centre, Dept Lands and Survey Technical Report (in prep).

Gibowicz S J (1973). "Variation of the Frequency-Magnitude Relationship During Taupo Earthquake Swarm of 1964-65." NZ Journal of Geology and Geophysics 16: 18-52.

Hunt $T$ M, Latter J H (1982). "A Survey of Seismic Activity Near Wairakei Geothermal Field, New Zealand." Journal of Volcanological and Geothermal Research $14: 319-334$.

Lowry M A (ed) (1983). "New Zealand Seismological Report 1982." Seismological Observatory Bulletin E-165. Department of Scientific and Industrial Research, Wellington.

Nairn I A (1973). "Geothermal Resource Survey, Waiotapu-Waimangu Region." Unpublished report, NZ Geological Survey open file.

Robinson R (1979). "Variation of Energy Release, Rate of Occurrence and b-Value of Earthquakes in the Main Seismic Region, New Zealand." Physics of the Earth and Planetary Interiors 18: 209-220.

Sissons B A (1979). "The Horizontal Kinematics of the North Island of New Zealand." PhD Thesis, Victoria University of wellington.

Smith W D (1978). "Spatial Distribution of Felt Intensities for New Zealand Earthquakes." NZ Journal of Geology and Geophysics $21: 293-312$.

Smith W D, Berryman K R (1984). "Earthquake Hazard in New Zealand: Inferences from Seismology and Geology." In Press, Proceedings of the International Symposium on Recent Crustal Movements, Wellington, 1984 .

Figure 4

First motions of $\mathrm{P}$-wave arrivals from the 14 December 1983 event (upper hemisphere, equal area projection). Solid and open symbols denote compressions and dilatations respectively, and ' $x$ ' denotes a nodal arrival. The ' $x$ ' near the centre of the plot represents arrivals from aftershocks at the temporary station installed in the epicentral region. One nodal plane is well determined. The heavy solid line denotes the locus of the tension axis for positions of the second nodal plane between the limits indicated by the dashed lines.

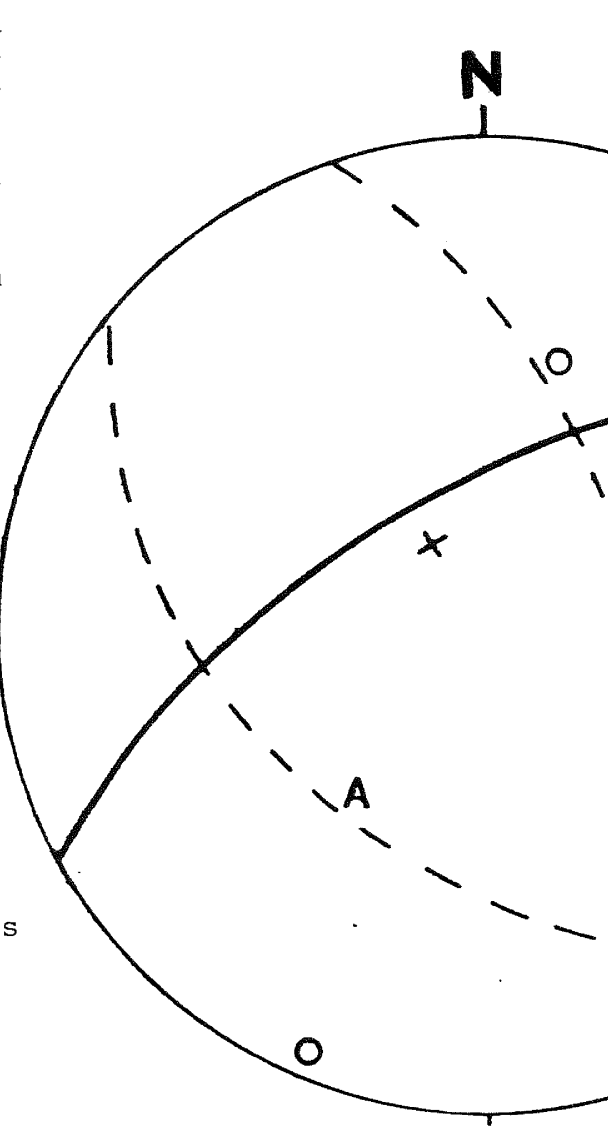




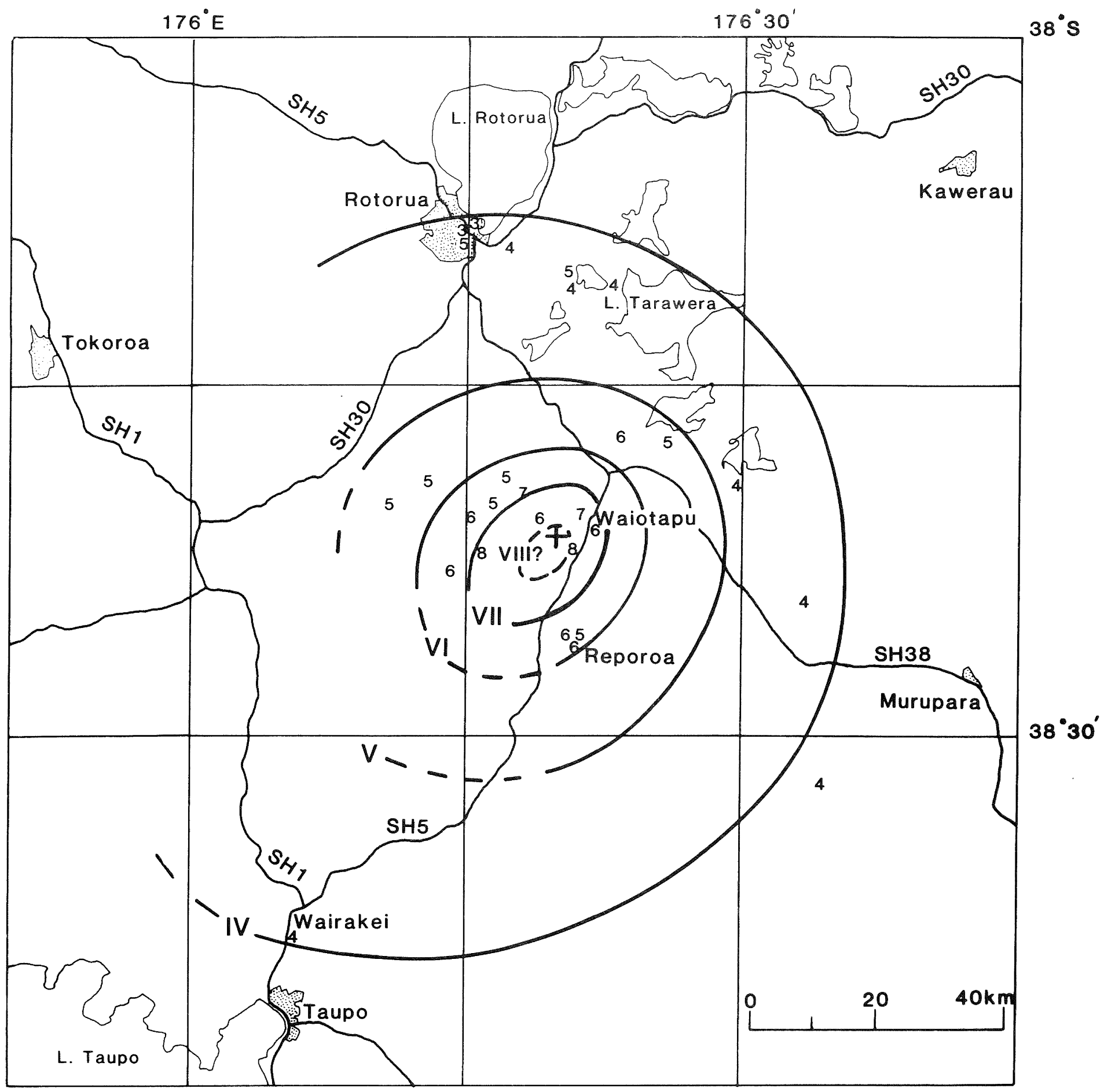

Figure 5

Isoseismals for the 14 December 1983 shock.

The main-shock epicentre is indicated by

the ' + '. 